\title{
Clean Air Journal: 1971 - 2014
}

Kornelius, $\mathrm{G}^{1}$ and Wright, $\mathrm{C}^{2}$

University of Pretoria

Council for Scientific and Industrial Research

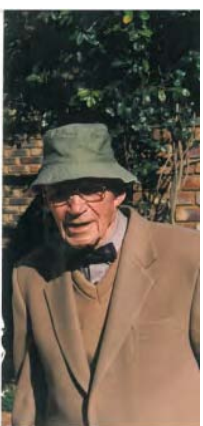

As the Clean Air Journal moves into its fifth decade of existence, several exciting changes have taken place. The journal was launched online with its own dedicated website

Figure 1. Prof Halliday www.cleanairjournal.org.za in December 2013. A new team of Co-Editors, namely Dr Gregor Feig, Dr Rebecca Garland and Dr Caradee Wright, were appointed in October of 2014. They took over from Dr Gerrit Kornelius who had been the Editor-in-Chief of the journal for 25 years. Seven reputable scientists, policy-makers and practitioners were invited to become members of the Editorial Advisory Board to guide the strategic direction of the journal and to ensure articles of the highest standard. All of these efforts, among several other important activities, are focussed on a key objective for the journal. That is, to obtain for the journal accreditation by the Department of Higher Education and Training and ensure its inclusion in major citation databases, with the end goal of acquiring an impact factor. This will then place the Clean Air Journal as an important reference for publications on air quality, air pollution, its impacts on the environment and the management thereof in Southern Africa. In fact, this has been the core mandate of the journal since its inception as the official journal of the National Association for Clean Air.

The National Association for Clean Air (NACA) was formed in 1969 and became an affiliate of IUAPPA (the International Union of Air Pollution Prevention Associations) in 1970, gaining full membership in 1973. The 1988 and 2013 IUAPPA World Clean Air congresses were held in South Africa. NACA arose out of a proposal at a General Meeting of Contributors to the Air Pollution Research Fund at a conference on air pollution held by the Department of Health (then responsible for air pollution matters) just prior to the implementation of the Atmospheric Pollution Prevention Act in October of 1966. At a meeting on 21 April 1969 (the Act had by then come into force) the committee formed in 1966 reported back and NACA was officially formed. After the energetic Mr Jack Easterbrook became director in 1971, branches were formed in Durban, Port Elizabeth and Cape Town during 1972, followed by East London in 1974. A Transvaal branch (subsequently the Highveld branch) was formed in 1980. An Educational and Technical Sub-committee was also formed in 1972, and NACA made substantial contributions to research projects (e.g. for cleaner domestic stoves) and awarded student bursaries over the years. The first journal under the editorship of Dr Eric Halliday (Figure 1) of the CSIR was published in September of 1971.

In addition to the Clean Air Journal, a NACA newsletter was also published regularly. In the earliest, hard copy newsletter we have on record (printed in April 1992, Vol 8(11)), NACA advertised several conferences, including the $2^{\text {nd }}$ South African Conference on Indoor Environmental Quality, WasteCon '92 (Waste Management in a Changing Society) and the Clean Air Symposium Port Elizabeth (held by the Eastern Cape NACA branch). The newsletters also included information on the annual World Clean Air Congress, recently published source books on air pollution topics for South African scholars and international news, such as an international agreement on cutting emissions of volatile organic compounds (VOCs) that formed part of a protocol under the Convention on Long Range Transboundary Air Pollution drawn up by the UN Economic Commission in 1992.

In 1971, the NACA Council decided to launch a publication known as the Clean Air Journal. The Clean Air Journal was established as a bi-annual publication with issues being released in May/June and November/December of each year. Back then, the articles focussed on a range of air pollution related topics. In Vol 2(No 4) of 1976, an article on the practical aspects of air pollution control, written by $\mathrm{NH}$ Jackson, looked at the process alteration, containment, and bag filters, among other techniques available at that time. Policy was also discussed, for example, in an article on the national and international factors influencing changes in the policy of air pollution control (Sharp, 2(4) 1976). In an effort to compile a complete repository of all of the Clean Air Journal articles since its inception, all available issues have been scanned and individual articles have been uploaded to an archive database on the journal's website.

In conclusion, the future of the Clean Air Journal is full of promise. This first issue of 2014 will include, more than ever included previously, additional front material incorporated in journals such as the South African Journal of Science and the South African Medical Journal. A commentary on the highly topical debate around air pollution offsets is given by Dr Christiaan Pauw. While this material is not peer-reviewed, all of the research articles in the journal do undergo rigorous peer review by at least two independent scientists. Together, the editorial team endeavour to maximise the Clean Air Journal to its full potential and ensure that its contents is of the highest quality to be considered as dependable reference material on air quality in South Africa. 